EGU2020-1404

https://doi.org/10.5194/egusphere-egu2020-1404

EGU General Assembly 2020

(c) Author(s) 2020. This work is distributed under

the Creative Commons Attribution 4.0 License.

\title{
Crustal structure and evolution of the Niuafo'ou Microplate in the northeastern Lau Basin, Southwestern Pacific
}

Florian Schmid ${ }^{1}$, Heidrun Kopp ${ }^{1}$, Michael Schnabel ${ }^{2}$, Anke Dannowski ${ }^{1}$, Ingo Heyde ${ }^{2}$, Michael Riedel $^{1}$, Martin Engels ${ }^{2}$, Anouk Beniest ${ }^{3}$, Ingo Klaucke ${ }^{1}$, Nico Augustin ${ }^{1}$, Philipp Brandl ${ }^{1}$, Colin Devey ${ }^{1}$, and Mark Hannington ${ }^{1}$

${ }^{1}$ GEOMAR - Helmholtz Zentrum für Ozeanforschung, Kiel, Germany (fschmid@uni-bremen.de)

${ }^{2}$ BGR, Federal Institute for Geosciences and Natural Resources, Hannover, Germany

${ }^{3}$ Vrije Universiteit Amsterdam, The Netherlands

The northeastern Lau Basin is one of the fastest opening and magmatically most active back-arc regions on Earth. Although the current pattern of plate boundaries and motions in this complex mosaic of microplates is fairly well understood, the structure and evolution of the back-arc crust are not. We present refraction seismic, multichannel seismic and gravity data from a $300 \mathrm{~km}$ long east-west oriented transect crossing the Niuafo'ou Microplate (back-arc), the Fonualei Rift and Spreading Centre (FRSC) and the Tofua Volcanic Arc at $17^{\circ} 20^{\prime} \mathrm{S}$. Our P wave tomography model shows strong lateral variations in the thickness and velocity-depth distribution of the crust. The thinnest crust is present in the Fonualei Rift and Spreading Center, suggesting active seafloor spreading there. In the much thicker crust of the volcanic arc we identify a region of anomalously low velocities, indicative of partial melts. Surprisingly, the melt reservoir is located at $\sim 17 \mathrm{~km}$ distance to the volcanic front, supporting the hypothesis that melts are deviated from the volcanic arc towards the FRSC in sub-crustal domains. We identify two distinct regions in the back-arc crust, representing different opening phases of the northeastern Lau Basin. During initial extension, likely dominated by rifting, crust of generally lower upper-crustal velocities formed. During an advanced opening phase, likely dominated by seafloor spreading, crust of higher upper-crustal velocities formed and is now up to $11 \mathrm{~km}$ thick. This thickening is the result of magmatic underplating, which is supported by elevated upper mantle temperatures in this region. 